\title{
Assessment of the Fractionation Patterns and Effects of Leaching Of Some Selected Heavy Metals in Owerri Industrial Layout, Nigeria
}

\author{
H. O. Abugu ${ }^{1}$, C. P. Ofordile ${ }^{2}$, Oyeudo, I. P. ${ }^{1}$ and U. C. Umeobika ${ }^{1}$ \\ ${ }^{I}$ (Pure \& Industrial Chemistry Department, Nnamdi Azikiwe University, Awka, Anambra State, Nigeria) \\ ${ }^{2}$ (Industrial Department, National Environmental Standard Regulatory and Enforcement Agency (NESREA) \\ Nigeria)
}

\begin{abstract}
Fractionation of $\mathrm{Cu}, \mathrm{Ca}, \mathrm{Mn}, \mathrm{Pb}, \mathrm{Ni}, \mathrm{Fe}, \mathrm{Co}, \mathrm{Zn}, \mathrm{Cr}$, and $\mathrm{Cd}$ was carried out on 30cm depth soil samples collected along the major roads of Owerri Industrial layout, Nigeria, with a sequential extraction procedure in the rainy (April to July) season, using atomic absorption spectroscopy. The $\mathrm{pH}$ of the soil had a range of 6.2 to 6.8 while moisture content had a range of 10.023to 13.782. Fe was discovered to occur at elevated concentrations in all the soil samples with the highest concentration $(1462.480 \mathrm{mg} / \mathrm{kg})$. The metal with least concentration $(0.067 \mathrm{mg} / \mathrm{kg})$ was $\mathrm{Cd}$. Ca (52.070) was mostly abundant in the Exchangeable fraction while $\mathrm{Cu} \quad(1.984 \mathrm{mg} / \mathrm{kg}), \quad \mathrm{Mn}(12.169 \mathrm{mg} / \mathrm{kg}), \quad \mathrm{Pb} \quad(3.013 \mathrm{mg} / \mathrm{kg}), \quad \mathrm{Ni}(3.845 \mathrm{mg} / \mathrm{kg}), \quad \mathrm{Fe} \quad(1360.790 \mathrm{mg} / \mathrm{kg}), \quad \mathrm{Co}$ $(3.871 \mathrm{mg} / \mathrm{kg}), \mathrm{Zn}(46.259 \mathrm{mg} / \mathrm{kg}), \mathrm{Cr}(3.817 \mathrm{mg} / \mathrm{kg})$ and $\mathrm{Cd}(0.257 \mathrm{mg} / \mathrm{kg})$ were mostly abundant in Residual fraction. From the fractionation results, most of the metals had high abundance in Residual fraction indicating lithogenic origin and low bioavailability of the metals considered. The average potential mobility was calculated for the metals in the soil $30 \mathrm{~cm}$ depth and it was in the order: $\mathrm{Ca}>\mathrm{Cd}>\mathrm{Cu}>\mathrm{Pb}>\mathrm{Mn}>\mathrm{Co}>\mathrm{Fe}>\mathrm{Ni}>\mathrm{Cr}>\mathrm{Zn}$
\end{abstract}

Keywords: bioavailability, concentration, extraction, residual, sequential.

\section{Introduction}

In soils, elements of interest exist in several different forms and are associated with a range of components [1]. Heavy metals concentration in soil are associated with biological and geochemical cycles and are influenced by anthropogenic activities such as agricultural practices, industrial activities and waste disposal methods [2]. Speciation can be defined as identification and quantification of the different species or forms of phases in which the elements occur. It is generally recognized that information about the physico-chemical forms of the elements is required for understanding their mobility, pathways and bioavailability. Studies on the distribution and speciation of heavy metals in soil can provide not only information on the degree of pollution, but specially the actual environmental impact, metal bioavailability as well as their origin [3]. Speciation techniques were useful in studies of metal partitioning, distribution, accumulation, and mobility in soil to support hypothesis and to gain a better understanding on the different processes and mechanism hypothesized. Today it is generally recognized that the particular behaviour of trace metals in the environment is determined by their specific physicochemical forms rather than by their total concentration. Speciation of metals largely determines their bioavailability and toxicity [1].

Heavy metals usually occur in soil at low concentration as a result of weathering and other pedigenic processes acting as the parent materials on which the soil develops. The natural occurrence of heavy metals varies between rock types and certain bed-rocks which provide exceptionally high metal concentration to overlying soils. Soils are clearly of enormous environmental importance, being the media that support virtually all plants life; hence their potential for environmental pollution requires attention $[4,5]$. While soils are important sinks for heavy metals, they can also release them into the ecosystem. It is therefore important to understand the content, chemistry and geology of heavy metals in soil as well as the chemical forms. However, the determination of specific chemical species or binding forms is difficult and often virtually impossible. For this reason, sequential extraction procedures are commonly applied because they provide information about the fractionation of metals in the different lattices of the solid sample, which is a good compromise method that gives information on the environmental contamination [6,7]. Polluted soils constitute major environmental problems and therefore are subjected to detailed risk assessment and management studies.

In this paper, soil samples collected from five major roads of Owerri industrial layout were examined to systematically study the speciation of some heavy metals in the soil which allows a distinction to be made between residual metals (insoluble forms) and metal bound to organic matter, iron and manganese oxide, carbonate and exchangeable, water soluble (soluble forms). This evaluation gives a relative distribution of $\mathrm{Cu}$, $\mathrm{Ca}, \mathrm{Mn}, \mathrm{Pb}, \mathrm{Ni}, \mathrm{Fe}, \mathrm{Co}, \mathrm{Zn}, \mathrm{Cr}$, and $\mathrm{Cd}$ fraction in the soluble (bioavailable) and insoluble (non-bioavailable 
form) using FAAS to assess their potential environmental impacts. This is in continuation of the recommendation made by Abugu, et al (2012) in the "'evaluation of the speciation patterns of some heavy metals along the major roads of Owerri industrial layout",

\section{Materials And Methods}

Soil samples were collected in the vicinity of Owerri Industrial layout between April and July. The sampling site comprised of five major roads, Raycon road (road 1), Gmicord road (road 2), Coca-cola road (road 3), Modern Home Aluminum road (road 4) and Assumpta Press road (road 5) covering the whole length of the area. A total of 5 samples were collected from each road and merged to form a composite sample, a representative of each road using a plastic scoop into a polythene bag well labelled. The sampling site is surrounded by industries. A residential estate (Graceland/Egbeada Estate) is located north - east of the estate. Also to the south - east of the industrial layout is located another estate (Umuguma Housing Estate) and on the north - east is a highway (Onitsha - Owerri Road).

In the laboratory, samples were dried at room temperature and sieved through a 200mesh before analysis. Drying sediments at higher temperature was avoided to ensure that organic matter content and the metal binding properties of the sediments remained intact. Care was also taken while sieving the sediments to prevent excess loss of the fine particles. All chemicals and acids used were of Analytical Reagent Grade (ARG), and were used without further purification.

\subsection{Procedure for Moisture Content Determination}

The moisture content of the samples was determined using the dry-weight-difference method.

\subsection{Procedure for $\mathrm{pH}$ Determination}

$5 \mathrm{~g}$ of the soil sample was weighed into $250 \mathrm{ml}$ Beaker and $20 \mathrm{ml}$ of deionized water added. It was agitated for about 20minutes and allowed to equilibrate. Finally, a standardized $\mathrm{pH}$ meter was used to read the $\mathrm{pH}$ by dipping the electrode into the $250 \mathrm{ml}$ Beaker containing the solution.

\subsection{Procedure for Determination of Total Metal Content}

About $5 \mathrm{~g}$ of the soil sample was weighed into sample rubber and $5 \mathrm{ml}$ of Hydrofluoric acid (HF) added. Also $10 \mathrm{ml}$ Aqua Regia(3:1) was added and the mixture heated over water bath for 1hour, 30minutes. Then, it was allowed to cool. The process was repeated again and $20 \mathrm{ml}$ boric acid was added. Thereafter, the solution was filtered and made-up to $50 \mathrm{ml}$ with deionized water. Finally, analysis of the extracts was carried out by Flame Atomic Absorption Spectrometry (Analyst 200).

\subsection{Sequential Extraction}

Sequential extraction protocol for analysis of heavy metal speciation in soil and sediments (modified from Tessier et al., 1979) were used to establish the association of the total concentration of the metals in the soil samples with their contents in the water soluble, exchangeable, carbonate, reducible (Fe/Mn oxide), oxidisable (organic and sulfide bound) and residual fraction [8].

\section{Results And Discussion}

The moisture contents and the $\mathrm{pH}$ of the various soil samples collected from the five major roads are as shown below (Table 1). The $\mathrm{pH}$ of the soil is an important parameter that directly influences mineral mobility. The soil $\mathrm{pH}$ of the sampling sites varied on the average from 6.2 to 6.8 in water indicating of slight acidity to neutrality. The moisture contents fell within the range of $10.023 \%$ to $13.782 \%$. Looking at table 1 , it showed that sample RY1 - RY5 had relatively high values of moisture contents indicating that the samples were collected during the rainy season and as well $30 \mathrm{~cm}$ depth from soil surface.

Table 1: Percentage Moisture Content and the $\mathrm{pH}$ of the Soil Samples.

\begin{tabular}{|l|l|l|}
\hline Sample code & \% Moisture Content & $\mathrm{pH}$ \\
\hline R1Y & 13.782 & 6.2 \\
\hline R2Y & 12.280 & 6.3 \\
\hline R3Y & 11.289 & 6.8 \\
\hline R4Y & 11.785 & 6.5 \\
\hline R5Y & 10.023 & 6.7 \\
\hline
\end{tabular}

NOTE: $\mathrm{R}$ is refer to as road were the sample was collected, Numbers $1-5$ represent the road numbers, and Y represent the soil sample $30 \mathrm{~cm}$ depth. 
Table 2: Total Metal Concentration for Soil $30 \mathrm{~cm}$ Depth $(\mathrm{mg} / \mathrm{kg})$.

\begin{tabular}{|l|l|l|l|l|l|l|l|l|l|l|l|l|}
\hline $\begin{array}{l}\text { Samp } \\
\text { le } \\
\text { code }\end{array}$ & $\mathrm{Cu}$ & $\mathrm{Ca}$ & $\mathrm{Mn}$ & $\mathrm{Pb}$ & $\mathrm{Ni}$ & $\mathrm{Fe}$ & $\mathrm{Co}$ & $\mathrm{Zn}$ & $\mathrm{Cr}$ & $\mathrm{Cd}$ & Total & Mean \\
\hline RY1 & 0.566 & 1.250 & 5.220 & 1.432 & 1.528 & 6.300 & 1.192 & 2.911 & 1.890 & 0.092 & 22.381 & 2.238 \\
& \pm 0.00 & \pm 0.00 & \pm 0.000 & \pm 0.01 & \pm 0.00 & \pm 0.012 & \pm 0.05 & \pm 0.01 & \pm 0.00 & \pm 0.00 & & \\
& 2 & 4 & & 1 & 5 & & 1 & 3 & 9 & 0 & & \\
\hline RY2 & 0.374 & 0.634 & 4.037 & 2.111 & 1.396 & 830.28 & 1.172 & 1.487 & 1.348 & 0.148 & 842.84 & 84.29 \\
& \pm 0.00 & \pm 0.01 & \pm 0.059 & \pm 1.12 & \pm 0.02 & 0 & \pm 0.02 & \pm 0.05 & \pm 0.03 & \pm 0.00 & 7 & 9 \\
& 4 & 9 & & 8 & 2 & \pm 0.069 & 9 & 4 & 3 & 3 & & \\
\hline RY3 & 0.811 & 0.306 & 16.291 & 2.709 & 1.685 & 1450.3 & 1.399 & 3.423 & 4.326 & 0.164 & 1481.4 & 148.1 \\
& \pm 0.00 & \pm 0.00 & \pm 0.031 & \pm 0.74 & \pm 0.00 & 60 & \pm 0.00 & \pm 0.00 & \pm 0.00 & \pm 0.01 & 74 & 47 \\
& 4 & 7 & & 9 & 2 & \pm 0.003 & 5 & 8 & 4 & 1 & & \\
\hline RY4 & 0.846 & 0.285 & 4.578 & 1.558 & 1.526 & 1462.4 & 1.254 & 3.069 & 3.759 & 0.158 & 1479.5 & 147.9 \\
& \pm 0.00 & \pm 0.01 & \pm 0.054 & \pm 0.03 & \pm 0.02 & 80 & \pm 0.01 & \pm 0.00 & \pm 0.00 & \pm 0.00 & 16 & 52 \\
& 2 & 5 & & 1 & 7 & \pm 0.162 & 8 & 1 & 4 & 4 & & \\
\hline RY5 & 0.744 & 0.910 & 5.330 & 1.308 & 0.492 & 6.321 & 1.247 & 2.621 & 3.111 & 0.160 & 22.244 & 2.224 \\
& \pm 0.00 & \pm 0.01 & \pm 0.005 & \pm 0.00 & \pm 0.05 & \pm 0.031 & \pm 0.01 & \pm 0.00 & \pm 0.00 & \pm 0.00 & & \\
& 1 & 1 & & 1 & 1 & & 8 & 2 & 1 & 4 & & \\
\hline Total & 3.344 & 3.389 & 35.456 & 9.118 & 6.627 & 3755.7 & 6.264 & 13.51 & 14.43 & 0.722 & $\mathbf{3 8 4 8 . 6}$ & \\
& & & & & & 41 & & 1 & 4 & & $\mathbf{0 2}$ & \\
\hline Mean & 0.669 & 0.677 & 7.091 & 1.824 & 1.325 & 751.14 & 1.253 & 2.702 & 2.887 & 0.144 & $\mathbf{7 6 9 . 7 2}$ & \\
& & & & & & 8 & & & & & & \\
\hline
\end{tabular}

The FAAS (Analyst 200) analysis result of the soil samples $30 \mathrm{~cm}$ depth are as tabulated (Table 2) and shown statistically in figure 1 . It was observed that Fe had the maximum concentration $(6.300 \mathrm{mg} / \mathrm{kg}, 830.280 \mathrm{mg} / \mathrm{kg}$, $1450.350 \mathrm{mg} / \mathrm{kg}, 1462.480 \mathrm{mg} / \mathrm{kg}$, and $6.321 \mathrm{mg} / \mathrm{kg}$ in samples RY1, RY2, RY3, RY4 and RY5 respectively), Cd had the least concentration $(0.092 \mathrm{mg} / \mathrm{kg}, 0.148 \mathrm{mg} / \mathrm{kg}, 0.164 \mathrm{mg} / \mathrm{kg}, 0.158 \mathrm{mg} / \mathrm{kg}$ and $0.160 \mathrm{mg} / \mathrm{kg}$ in RY1, RY2, RY3, RY4 and RY5 respectively also). The observed trends in the various samples are as follows: $\mathrm{Fe}>\mathrm{Mn}>\mathrm{Zn}$ $>\mathrm{Cr}>\mathrm{Ni}>\mathrm{Pb}>\mathrm{Ca}>\mathrm{Co}>\mathrm{Cu}>\mathrm{Cd}$ for sample $\mathrm{RY} 1, \mathrm{Fe}>\mathrm{Mn}>\mathrm{Pb}>\mathrm{Zn}>\mathrm{Ni}>\mathrm{Cr}>\mathrm{Co}>\mathrm{Ca}>\mathrm{Cu}>\mathrm{Cd}$ for sample $\mathrm{RY} 2, \mathrm{Fe}>\mathrm{Mn}>\mathrm{Cr}>\mathrm{Zn}>\mathrm{Pb}>\mathrm{Ni}>\mathrm{Co}>\mathrm{Cu}>\mathrm{Ca}>\mathrm{Cd}$ for sample $\mathrm{RY} 3$ while $\mathrm{Fe}>\mathrm{Mn}>\mathrm{Cr}>\mathrm{Zn}>$ $\mathrm{Pb}>\mathrm{Ni}>\mathrm{Co}>\mathrm{Cu}>\mathrm{Ca}>\mathrm{Cd}$ and $\mathrm{Fe}>\mathrm{Mn}>\mathrm{Cr}>\mathrm{Zn}>\mathrm{Pb}>\mathrm{Co}>\mathrm{Ca}>\mathrm{Cu}>\mathrm{Ni}>\mathrm{Cd}$ are for $\mathrm{RY} 4$ and $\mathrm{RY} 5$ respectively. The observed trend in the metal mean concentrations of the various soil samples $30 \mathrm{~cm}$ depth was $\mathrm{Fe}>\mathrm{Mn}>\mathrm{Cr}>\mathrm{Zn}>\mathrm{Pb}>\mathrm{Ni}>\mathrm{Co}>\mathrm{Ca}>\mathrm{Cu}>\mathrm{Cd}$.

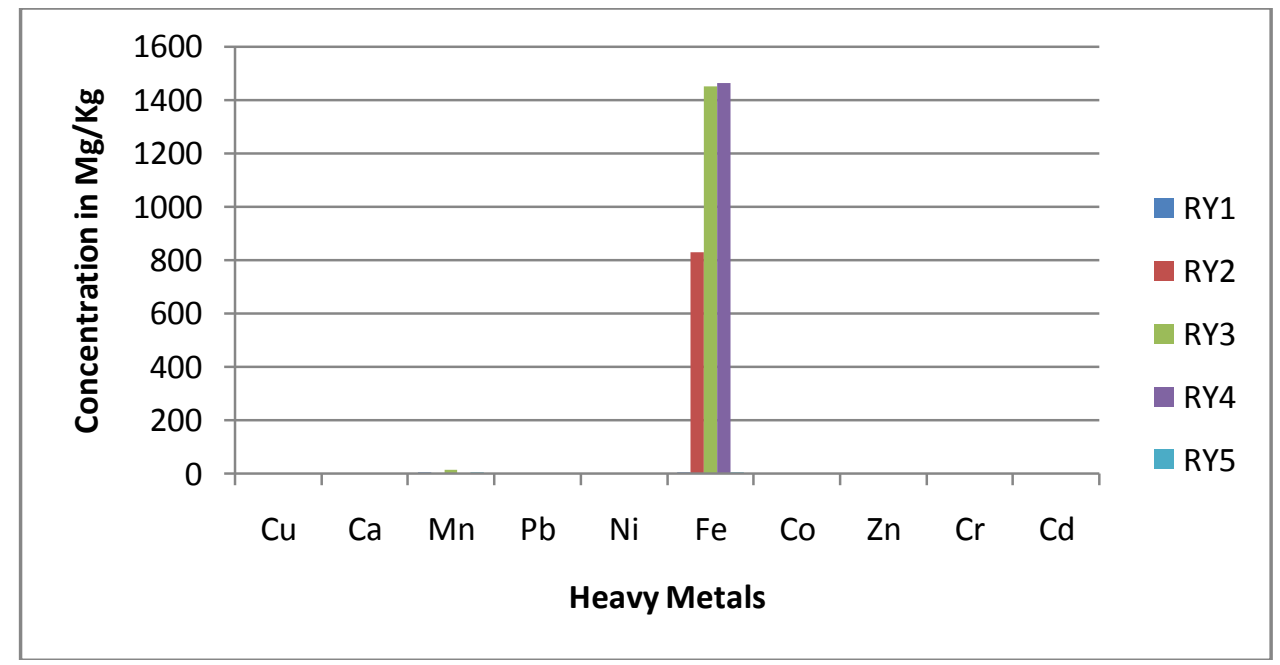

Figure 1: Total Metal Concentration for Soil 30cm Depth.

Figure 1 shows the mean metal concentrations with Fe having the most elevated concentration in almost all the soil sample and $\mathrm{Ca}$ being the next with $\mathrm{Cd}$ having the least concentration in almost all the soil samples. 
Table 3: Percentage Total Metal Concentration 30cm Depth

\begin{tabular}{|l|l|l|l|l|l|l|l|l|l|l|}
\hline $\begin{array}{l}\text { Sample } \\
\text { code }\end{array}$ & $\mathrm{Cu}$ & $\mathrm{Ca}$ & $\mathrm{Mn}$ & $\mathrm{Pb}$ & $\mathrm{Ni}$ & $\mathrm{Fe}$ & $\mathrm{Co}$ & $\mathrm{Zn}$ & $\mathrm{Cr}$ & $\mathrm{Cd}$ \\
\hline RY1 & 2.529 & 5.585 & 23.323 & 6.398 & 6.827 & 28.149 & 5.326 & 13.007 & 8.445 & 0.411 \\
\hline RY2 & 0.044 & 0.075 & 0.479 & 0.250 & 0.166 & 98.493 & 0.139 & 0.176 & 0.160 & 0.018 \\
\hline RY3 & 0.055 & 0.021 & 1.100 & 0.183 & 0.114 & 97.900 & 0.094 & 0.231 & 0.292 & 0.011 \\
\hline RY4 & 0.057 & 0.019 & 0.309 & 0.105 & 0.103 & 98.849 & 0.085 & 0.207 & 0.254 & 0.011 \\
\hline RY5 & 3.345 & 4.046 & 23.962 & 5.880 & 2.212 & 28.417 & 5.606 & 11.783 & 13.986 & 0.719 \\
\hline
\end{tabular}

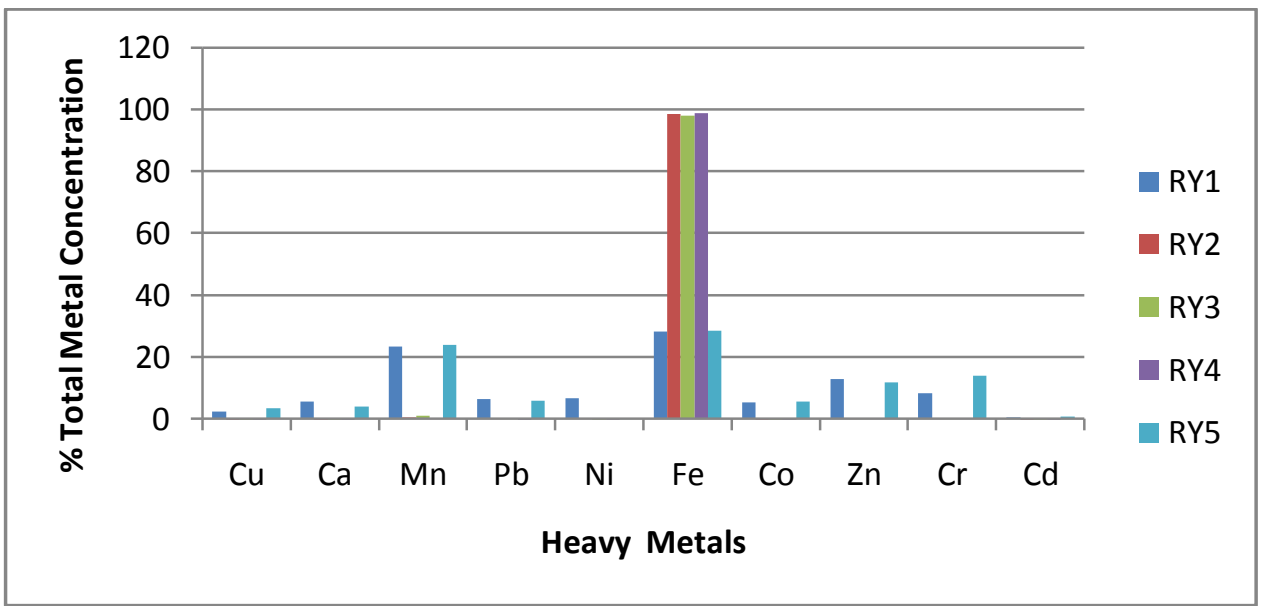

Figure 2: Percentage Total Metal Concentration of Soil 30cm Depth

The fractional concentration of $\mathrm{Cu}$ in the soil $30 \mathrm{~cm}$ depth is as presented in table 4 . Here much of the copper was associated with the residual fraction (F6) with a mean value of $0.387 \mathrm{mg} / \mathrm{kg}$. Cu was not detected in samples RY3 and RY4 at the water soluble fraction. The observed trend in the range of concentration of copper was F6 > F2 $>$ F5 $>$ F3 $>$ F4 > F1. The \%BAF of $\mathrm{Cu}$ in all the samples followed the trend RY1 > RY4 $>$ RY5 > RY2 > RY3. The mean \%BAF is 37.281 and so was generally low for most of the samples.

Table 4: Fractional Concentration of $\mathrm{Cu}$ in the Various Soils $30 \mathrm{~cm}$ Depth $(\mathrm{mg} / \mathrm{kg})$.

\begin{tabular}{|c|c|c|c|c|c|c|c|c|c|c|}
\hline $\begin{array}{l}\text { Sample } \\
\text { code }\end{array}$ & F1 & $\mathrm{F} 2$ & F3 & F4 & F5 & F6 & Total & Mean & BAF & $\% \mathrm{BAF}$ \\
\hline RY1 & $\begin{array}{l}0.011 \\
\pm 0.001\end{array}$ & $\begin{array}{l}0.081 \\
\pm 0.001\end{array}$ & $\begin{array}{l}0.180 \\
\pm 0.000\end{array}$ & $\begin{array}{l}0.099 \\
\pm 0.003\end{array}$ & $\begin{array}{l}0.136 \\
\pm 0.004\end{array}$ & $\begin{array}{l}0.212 \\
\pm 0.002\end{array}$ & 0.719 & 0.090 & 0.272 & 50.464 \\
\hline RY2 & $\begin{array}{l}0.001 \\
\pm 0.003\end{array}$ & $\begin{array}{l}0.096 \\
\pm 0.000\end{array}$ & $\begin{array}{l}0.137 \\
\pm 0.000\end{array}$ & $\begin{array}{l}0.082 \\
\pm 0.002\end{array}$ & $\begin{array}{l}0.144 \\
\pm 0.001\end{array}$ & $\begin{array}{l}0.382 \\
\pm 0.093\end{array}$ & 0.842 & 0.140 & 0.234 & 27.791 \\
\hline RY3 & ND & $\begin{array}{l}0.050 \\
\pm 0.004\end{array}$ & $\begin{array}{l}0.120 \\
\pm 0.000\end{array}$ & $\begin{array}{l}0.078 \\
\pm 0.003\end{array}$ & $\begin{array}{l}0.225 \\
\pm 0.001\end{array}$ & $\begin{array}{l}0.648 \\
\pm 0.003\end{array}$ & 1.121 & 0.187 & 0.170 & 15.165 \\
\hline RY4 & ND & $\begin{array}{l}0.407 \\
\pm 0.003\end{array}$ & $\begin{array}{l}0.128 \\
\pm 0.000\end{array}$ & $\begin{array}{l}0.045 \\
\pm 0.000\end{array}$ & $\begin{array}{l}0.117 \\
\pm 0.001\end{array}$ & $\begin{array}{l}0.360 \\
\pm 0.003\end{array}$ & 1.057 & 0.176 & 0.535 & 50.615 \\
\hline RY5 & $\begin{array}{l}0.029 \\
\pm 0.001 \\
\end{array}$ & $\begin{array}{l}0.550 \\
\pm 0.000 \\
\end{array}$ & $\begin{array}{l}0.151 \\
\pm 0.002\end{array}$ & $\begin{array}{l}0.110 \\
\pm 0.003 \\
\end{array}$ & $\begin{array}{l}0.550 \\
\pm 0.005\end{array}$ & $\begin{array}{l}0.333 \\
\pm 0.008 \\
\end{array}$ & 1.723 & 0.287 & 0.730 & 42.368 \\
\hline Total & 0.041 & 1.184 & 0.716 & 0.414 & 1.172 & 1.935 & 5.462 & 0.910 & 1.941 & 186.403 \\
\hline Mean & 0.008 & 0.237 & 0.143 & 0.083 & 0.234 & 0.387 & 1.092 & 0.182 & 0.388 & 37.281 \\
\hline
\end{tabular}




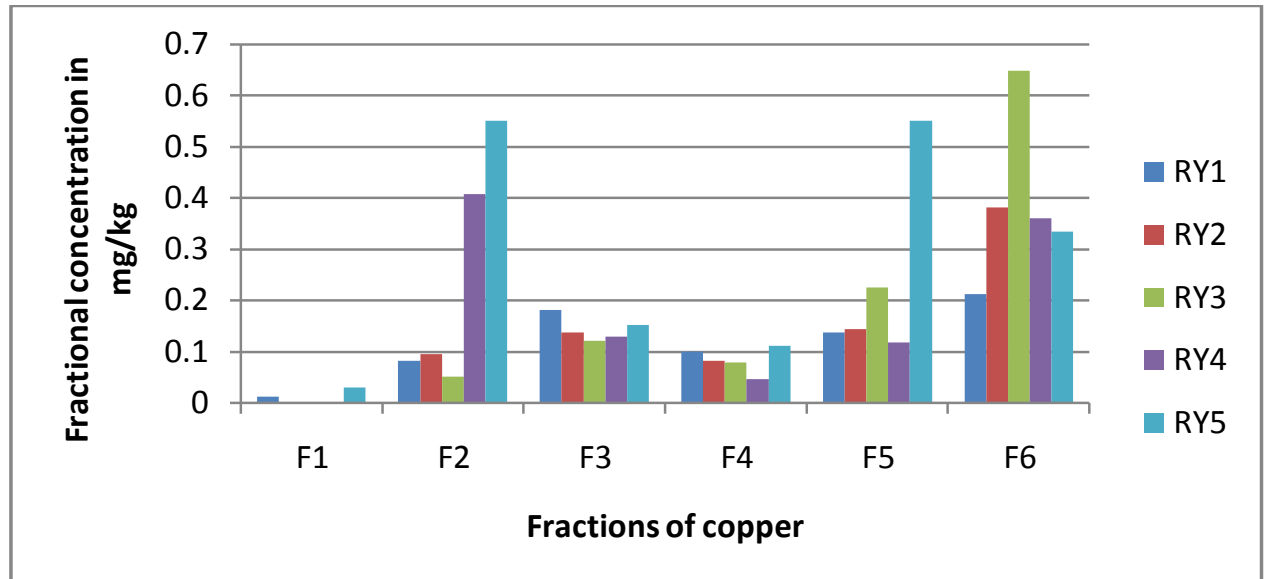

Figure 3: Fractional Concentration of $\mathrm{Cu}$ in the Various Soils 30cm Depth $(\mathrm{mg} / \mathrm{kg})$.

Represented in table 5 is the fractional concentration of $\mathrm{Ca}$ in soil sample $30 \mathrm{~cm}$ depth. Sample RY2 had the highest concentration of $\mathrm{Ca}(18.900 \mathrm{mg} / \mathrm{kg})$ in the fraction and the least was recorded in sample $\mathrm{RY} 3$ $(0.008 \mathrm{mg} / \mathrm{kg})$ in the carbonate fraction though undetectable in sample RY4 at the carbonate bound fraction and so also it is in samples RY3 and RY4 at the oxidizable fraction.

Table 5: Fractional Concentration of Ca in the Various Soils 30 cm Depth $(\mathrm{mg} / \mathrm{kg})$.

\begin{tabular}{|l|l|l|l|l|l|l|l|l|l|l|l|}
\hline $\begin{array}{l}\text { Sample } \\
\text { code }\end{array}$ & F1 & F2 & F3 & F4 & F5 & F6 & Total & Mean & BAF & $\%$ BAF \\
\hline RY1 & 6.770 & 7.880 & 0.222 & 1.268 & 0.923 & 0.322 & 17.385 & 2.898 & 14.872 & 85.545 \\
& \pm 0.046 & \pm 0.019 & \pm 0.032 & \pm 0.081 & \pm 0.004 & \pm 0.002 & & & & \\
\hline RY2 & 9.382 & 10.857 & 1.172 & 2.442 & 0.579 & 0.250 & 24.682 & 4.114 & 21.411 & 86.747 \\
& \pm 0.295 & \pm 0.084 & \pm 0.016 & \pm 0.059 & \pm 0.006 & \pm 0.026 & & & & \\
\hline RY3 & 4.599 & 18.900 & 0.008 & 0.309 & ND & 0.338 & 24.154 & 4.026 & 23.507 & 97.321 \\
& \pm 0.052 & \pm 0.085 & \pm 0.008 & \pm 0.012 & & \pm 0.008 & & & & \\
\hline RY4 & 12.096 & 5.212 & ND & 0.905 & ND & 0.326 & 18.539 & 3.090 & 17.308 & 93.360 \\
& \pm 0.058 & \pm 0.080 & & \pm 0.009 & & \pm 0.019 & & & & \\
\hline RY5 & 8.966 & 9.221 & 0.962 & 0.668 & 0.323 & 0.216 & 20.356 & 3.393 & 19.149 & 94.071 \\
& \pm 0.049 & \pm 0.088 & \pm 0.001 & \pm 0.006 & \pm 0.021 & \pm 0.019 & & & & \\
\hline Total & 41.813 & 52.070 & 2.364 & 5.592 & 1.825 & 1.452 & 105.116 & 17.519 & 96.247 & 457.044 \\
\hline Mean & 8.363 & 10.414 & 0.473 & 1.118 & 0.365 & 0.290 & 21.023 & 3.504 & 19.250 & 91.409 \\
\hline
\end{tabular}

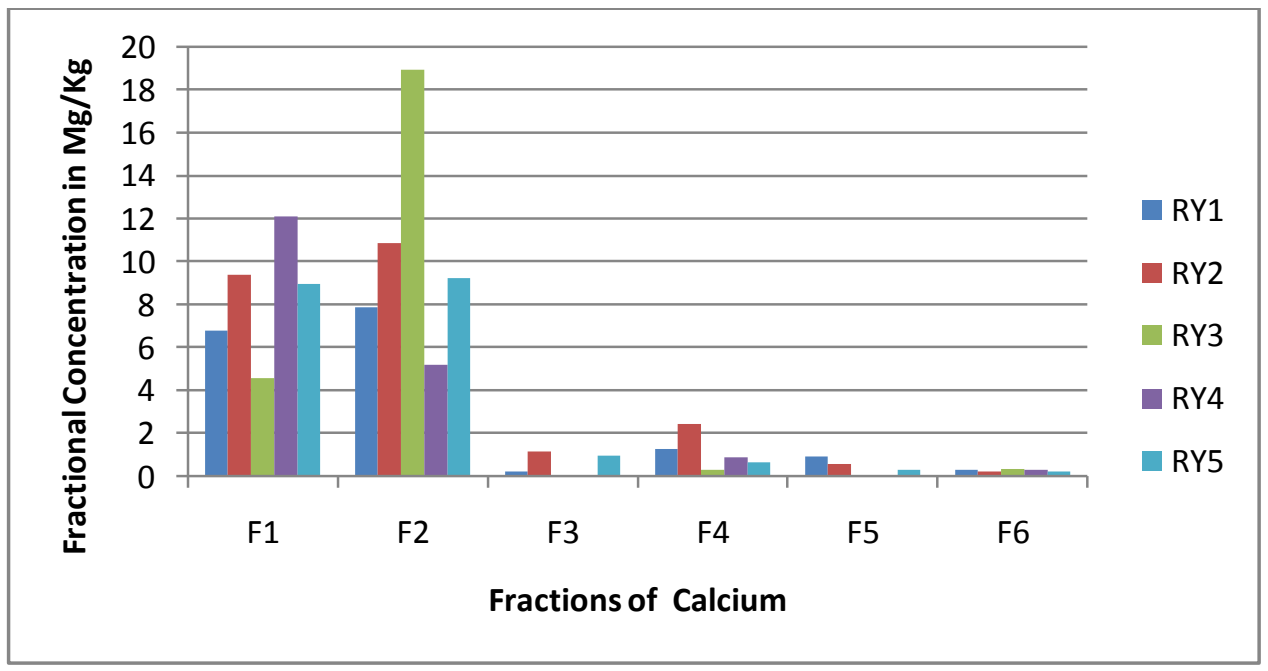

Figure 4: Fractional Concentration of Ca in the Various Soils 30 $\mathrm{cm}$ Depth $(\mathrm{mg} / \mathrm{kg})$.

The exchangeable fraction recorded the meanest value $(10.414 \mathrm{mg} / \mathrm{kg})$ and the residual fraction had the least $(0.290 \mathrm{mg} / \mathrm{kg})$. The observed trend in the mean concentration of $\mathrm{Ca}$ in the various fractions was $\mathrm{F} 2>\mathrm{F} 1>\mathrm{F} 4>$ F4 > F5 > F6. From the table, it can be observed that the \%BAF of all samples are very high and so we can infer that $\mathrm{Ca}$ is very bioavailable in the studied area. This is also supported by the low values recorded in the residual fractions (F6) of $\mathrm{Ca}$. Figure 4 shows that $\mathrm{Ca}$ fractionated more in the water soluble and the exchangeable fractions (F1 and F2). 
Table 6: Fractional Concentration of $\mathrm{Mn}$ in the Various Soils $30 \mathrm{~cm}$ Depth $(\mathrm{mg} / \mathrm{kg})$.

\begin{tabular}{|l|l|l|l|l|l|l|l|l|l|l|}
\hline $\begin{array}{l}\text { Sample } \\
\text { code }\end{array}$ & F1 & F2 & F3 & F4 & F5 & F6 & Total & Mean & BAF & \%AF \\
\hline RY1 & 0.121 & 0.819 & 0.925 & 1.321 & 1.668 & 2.661 & 7.515 & 1.253 & 1.865 & 24.817 \\
& \pm 0.012 & \pm 0.010 & \pm 0.003 & \pm 0.008 & \pm 0.012 & \pm 0.006 & & & & \\
\hline RY2 & 0.153 & 0.589 & 0.966 & 0.937 & 1.012 & 1.653 & 5.310 & 0.885 & 1.708 & 32.166 \\
& \pm 0.009 & \pm 0.011 & \pm 0.019 & \pm 0.012 & \pm 0.033 & \pm 0.038 & & & & \\
\hline RY3 & 0.262 & 0.416 & 1.018 & 1.214 & 1.176 & 2.826 & 6.912 & 1.152 & 1.696 & 24.537 \\
& \pm 0.001 & \pm 0.010 & \pm 0.017 & \pm 0.011 & \pm 0.100 & \pm 0.036 & & & & \\
\hline RY4 & 0.120 & 1.976 & 0.669 & 0.677 & 0.911 & 2.718 & 7.071 & 1.179 & 2.765 & 39.103 \\
& \pm 0.003 & \pm 0.027 & \pm 0.017 & \pm 0.022 & \pm 0.003 & \pm 0.064 & & & & \\
\hline RY5 & 0.216 & 1.233 & 0.923 & 1.102 & 0.988 & 2.311 & 6.773 & 1.129 & 2.372 & 35.021 \\
& \pm 0.016 & \pm 0.012 & \pm 0.031 & \pm 0.021 & \pm 0.023 & \pm 0.003 & & & & \\
\hline Total & 0.872 & 5.033 & 4.501 & 5.251 & 5.755 & 12.169 & 33.591 & 5.597 & 10.406 & 155.644 \\
\hline Mean & 0.174 & 1.007 & 0.900 & 1.050 & 1.151 & 2.434 & 6.716 & 1.119 & 2.081 & 31.129 \\
\hline
\end{tabular}

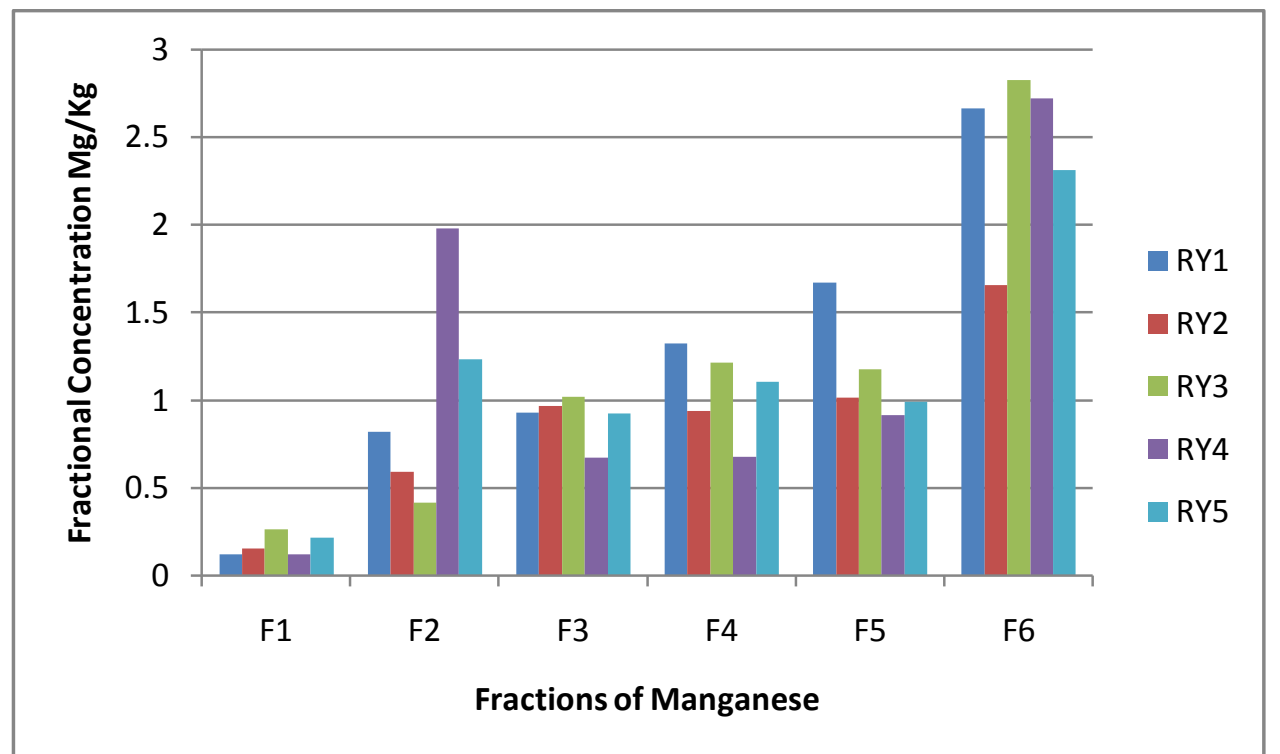

Figure 5: Fractional Concentration of $\mathrm{Mn}$ in the Various Soils 30cm Depth $(\mathrm{mg} / \mathrm{kg})$.

The fractional concentration of Mn showed that Mn concentration was most in the residual fraction with a mean value of $2.434 \mathrm{mg} / \mathrm{kg}$, and least in the water soluble fraction $(0.174 \mathrm{mg} / \mathrm{kg})$. The observed trend in the mean concentration of $\mathrm{Mn}$ in the various fractions is F6 $>$ F5 $>$ F4 $>$ F2 $>$ F3 $>$ F1 (Table 6). Also the observed trend in the \% BAF of the samples is RY4 $>$ RY5 $>$ RY2 $>$ RY1 $>$ RY3. We can infer that the Mn in the studied area fractionated more in the residual and so are from geochemical sources.

Table 7: Fractional Concentration of $\mathrm{Pb}$ in the Various Soils $30 \mathrm{~cm}$ Depth $(\mathrm{mg} / \mathrm{kg})$.

\begin{tabular}{|l|l|l|l|l|l|l|l|l|l|l|}
\hline Sample code & F1 & F2 & F3 & F4 & F5 & F6 & Total & Mean & BAF & \%AF \\
\hline RY1 & ND & $\begin{array}{l}0.042 \\
\pm 0.002\end{array}$ & $\begin{array}{l}0.204 \\
\pm 0.014\end{array}$ & ND & ND & $\begin{array}{l}0.802 \\
\pm 0.066\end{array}$ & 1.048 & 0.175 & 0.246 & 23.473 \\
\hline RY2 & ND & ND & $\begin{array}{l}0.048 \\
\pm 0.019\end{array}$ & ND & ND & $\begin{array}{l}0.265 \\
\pm 0.008\end{array}$ & 0.313 & 0.052 & 0.048 & 15.335 \\
\hline RY3 & ND & ND & $\begin{array}{l}0.178 \\
\pm 0.006\end{array}$ & ND & ND & $\begin{array}{l}0.756 \\
\pm 0.029\end{array}$ & 0.934 & 0.156 & 0.178 & 19.058 \\
\hline RY4 & ND & $\begin{array}{l}0.804 \\
\pm 0.002\end{array}$ & $\begin{array}{l}0.208 \\
\pm 0.034\end{array}$ & ND & ND & $\begin{array}{l}0.667 \\
\pm 0.018\end{array}$ & 1.679 & 0.280 & 1.012 & 60.274 \\
\hline RY5 & ND & $\begin{array}{l}0.542 \\
\pm 0.011\end{array}$ & $\begin{array}{l}0.062 \\
\pm 0.008\end{array}$ & $\begin{array}{l}0.006 \\
\pm 0.002\end{array}$ & ND & $\begin{array}{l}0.523 \\
\pm 0.016\end{array}$ & 1.133 & 0.189 & 0.604 & 53.310 \\
\hline Total & 0.000 & 1.388 & 0.700 & 0.006 & 0.000 & 3.013 & 5.107 & 0.851 & 2.088 & 171.423 \\
\hline Mean & 0.000 & 0.278 & 0.140 & 0.001 & 0.000 & 0.603 & 1.022 & 0.170 & 6.418 & 34.285 \\
\hline
\end{tabular}




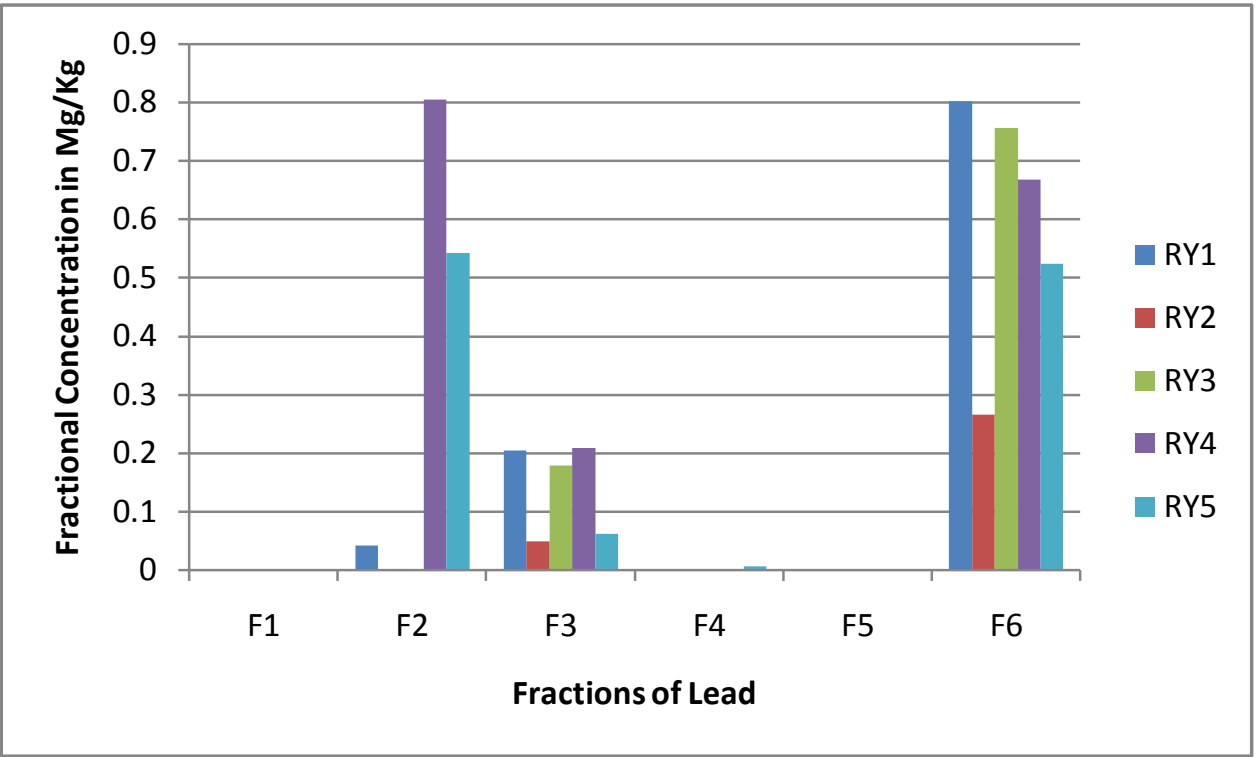

Figure 6: Fractional Concentration of $\mathrm{Pb}$ in the Various Soils 30cm Depth $(\mathrm{mg} / \mathrm{kg})$.

Table 7 showed that $\mathrm{Pb}$ was undetectable in the water soluble and the oxidisable fraction in all the samples. It was also undetectable in the reducible fraction except in sample RY5. The residual fraction had the meanest concentration of $\mathrm{Pb}(0.603 \mathrm{mg} / \mathrm{kg})$ and the least in reducible fraction $(0.001 \mathrm{mg} / \mathrm{kg})$. The observed trend was F6 > $\mathrm{F} 2>\mathrm{F} 3>\mathrm{F} 4>\mathrm{F} 5>\mathrm{F} 1$. This suggests that most $\mathrm{Pb}$ in the studied area is from geochemical sources. The bioavailability of $\mathrm{Pb}$ is generally low except for sample RY4 and RY5 were the \%BAF is slightly above $50 \%$.

Table 8: Fractional Concentration of Ni in the Various Soils $30 \mathrm{~cm}$ Depth $(\mathrm{mg} / \mathrm{kg})$.

\begin{tabular}{|l|l|l|l|l|l|l|l|l|l|l|}
\hline $\begin{array}{l}\text { Sample } \\
\text { code }\end{array}$ & F1 & F2 & F3 & F4 & F5 & F6 & Total & Mean & BAF & $\%$ BAF \\
\hline RY1 & 0.043 & 0.136 & 0.418 & 1.989 & 0.609 & 0.638 & 3.833 & 0.639 & 0.597 & 15.575 \\
& \pm 0.003 & \pm 0.006 & \pm 0.004 & \pm 0.003 & \pm 0.006 & \pm 0.005 & & & & \\
\hline RY2 & 0.037 & 0.115 & 0.206 & 0.035 & 0.057 & 0.642 & 1.092 & 0.182 & 0.358 & 32.784 \\
& \pm 0.001 & \pm 0.008 & \pm 0.003 & \pm 0.006 & \pm 0.002 & \pm 0.013 & & & & \\
\hline RY3 & 0.018 & 0.094 & 0.210 & 0.045 & 0.070 & 0.982 & 1.419 & 0.237 & 0.322 & 22.692 \\
& \pm 0.001 & \pm 0.002 & \pm 0.005 & \pm 0.001 & \pm 0.003 & \pm 0.011 & & & & \\
\hline RY4 & 0.033 & 0.507 & 0.218 & 0.020 & 0.069 & 0.859 & 1.706 & 0.284 & 0.758 & 44.431 \\
& \pm 0.008 & $\pm 0.006+$ & \pm 0.009 & \pm 0.000 & \pm 0.000 & \pm 0.011 & & & & \\
\hline RY5 & 0.039 & 0.124 & 0.328 & 0.309 & 0.810 & 0.724 & 2.334 & 0.389 & 0.491 & 21.037 \\
& \pm 0.001 & \pm 0.009 & \pm 0.008 & \pm 0.003 & \pm 0.008 & \pm 0.005 & & & & \\
\hline Total & 0.170 & 0.976 & 1.380 & 2.398 & 1.615 & 3.845 & 10.384 & 1.731 & 2.526 & 136.519 \\
\hline Mean & 0.034 & 0.195 & 0.276 & 0.480 & 0.323 & 0.769 & 2.077 & 0.346 & 0.505 & 27.304 \\
\hline
\end{tabular}

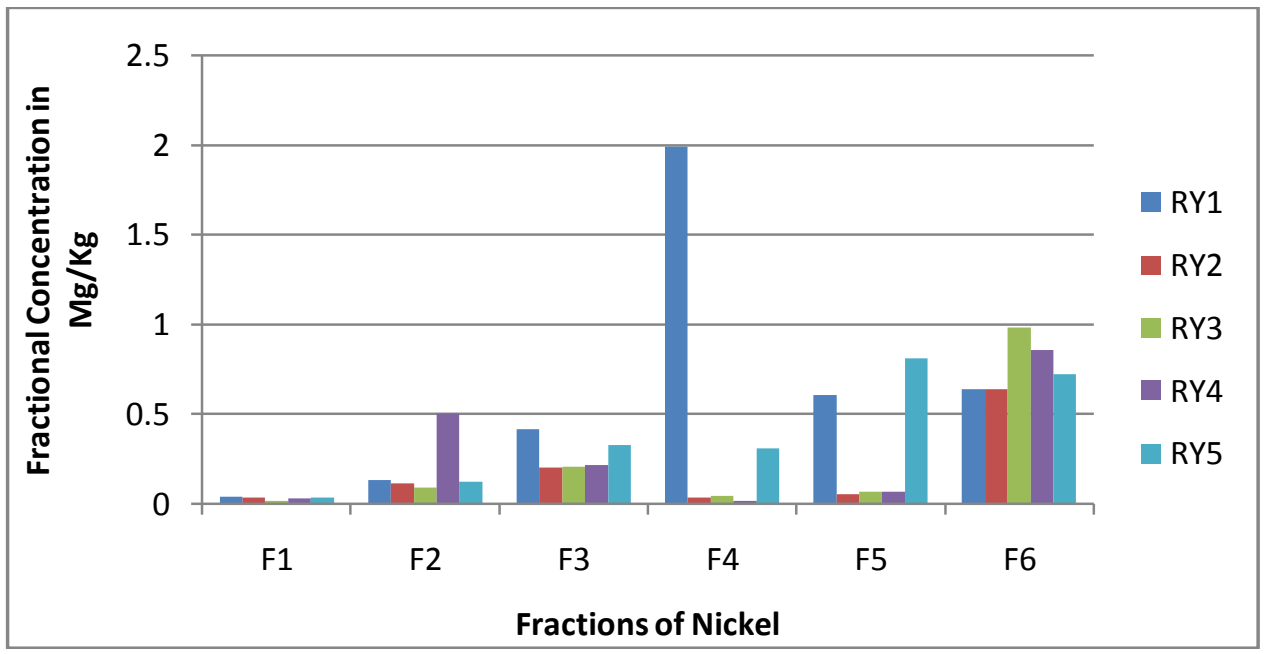

Figure 7: Fractional Concentration of Ni in the Various Soils 30cm Depth $(\mathrm{mg} / \mathrm{kg})$. 
$\mathrm{Ni}$ recorded its highest concentration in the residual fraction were the mean concentration is $0.769 \mathrm{mg} / \mathrm{kg}$ and the least in the water soluble fraction (Table 8). The trend in the mean concentration of the various fractions of $\mathrm{Ni}$ is F6 $>$ F4 $>$ F5 $>$ F3 $>$ F2 $>$ F1. Considering the \%BAF, it can be inferred that the non-bioavailable fractions is higher than those of bioavailable fraction since the \% BAF of all the samples were below $50 \%$, and the mean $\% \mathrm{BAF}$ is 27.304.

Table 9: Fractional Concentration of Fe in the Various Soils 30cm Depth (mg/kg).

\begin{tabular}{|c|c|c|c|c|c|c|c|c|c|c|}
\hline $\begin{array}{l}\text { Sample } \\
\text { code }\end{array}$ & F1 & $\mathrm{F} 2$ & F3 & F4 & $\overline{F 5}$ & F6 & Total & Mean & BAF & $\% \mathrm{BAF}$ \\
\hline RY1 & $\begin{array}{l}0.200 \\
\pm 0.010\end{array}$ & $\begin{array}{l}8.900 \\
\pm 0.023\end{array}$ & $\begin{array}{l}7.400 \\
\pm 0.556\end{array}$ & $\begin{array}{l}5.300 \\
\pm 0.096\end{array}$ & $\begin{array}{l}12.300 \\
\pm 0.112\end{array}$ & $\begin{array}{l}5.400 \\
\pm 0.014\end{array}$ & 39.500 & 6.583 & 16.500 & 41.772 \\
\hline RY2 & ND & $\begin{array}{l}8.837 \\
\pm 0.037\end{array}$ & $\begin{array}{l}13.062 \\
\pm 0.012\end{array}$ & $\begin{array}{l}31.941 \\
\pm 0.045\end{array}$ & $\begin{array}{l}76.839 \\
\pm 0.085\end{array}$ & $\begin{array}{l}270.480 \\
\pm 0.042\end{array}$ & 401.159 & 66.860 & 21.899 & 5.459 \\
\hline RY3 & ND & $\begin{array}{l}8.103 \\
\pm 0.052\end{array}$ & $\begin{array}{l}21.714 \\
\pm 0.013\end{array}$ & $\begin{array}{l}102.039 \\
\pm 0.129\end{array}$ & $\begin{array}{l}14.694 \\
\pm 0.090\end{array}$ & $\begin{array}{l}717.060 \\
\pm 0.076\end{array}$ & 863.610 & 143.935 & 29.817 & 3.453 \\
\hline RY4 & ND & $\begin{array}{l}279.300 \\
\pm 0.169\end{array}$ & $\begin{array}{l}69.237 \\
\pm 0.044\end{array}$ & $\begin{array}{l}45.171 \\
\pm 0.044\end{array}$ & $\begin{array}{l}203.040 \\
\pm 0.156\end{array}$ & $\begin{array}{l}360.150 \\
\pm 0.196\end{array}$ & 956.898 & 159.483 & 348.537 & 36.424 \\
\hline RY5 & $\begin{array}{l}0.600 \\
\pm 0.019\end{array}$ & $\begin{array}{l}7.500 \\
\pm 0.085\end{array}$ & $\begin{array}{l}9.500 \\
\pm 0.001\end{array}$ & $\begin{array}{l}7.500 \\
\pm 0.065\end{array}$ & $\begin{array}{l}2.000 \\
\pm 0.121\end{array}$ & $\begin{array}{l}7.700 \\
\pm 0.015\end{array}$ & 34.480 & 5.800 & 17.600 & 51.044 \\
\hline Total & 0.800 & 312.640 & 120.913 & 191.951 & 308.873 & 1360.790 & 2295.967 & 382.661 & 434.353 & 138.152 \\
\hline Mean & 0.160 & 62.528 & 24.182 & 38.390 & 61.775 & 272.159 & 459.194 & 76.532 & 86.870 & 27.630 \\
\hline
\end{tabular}

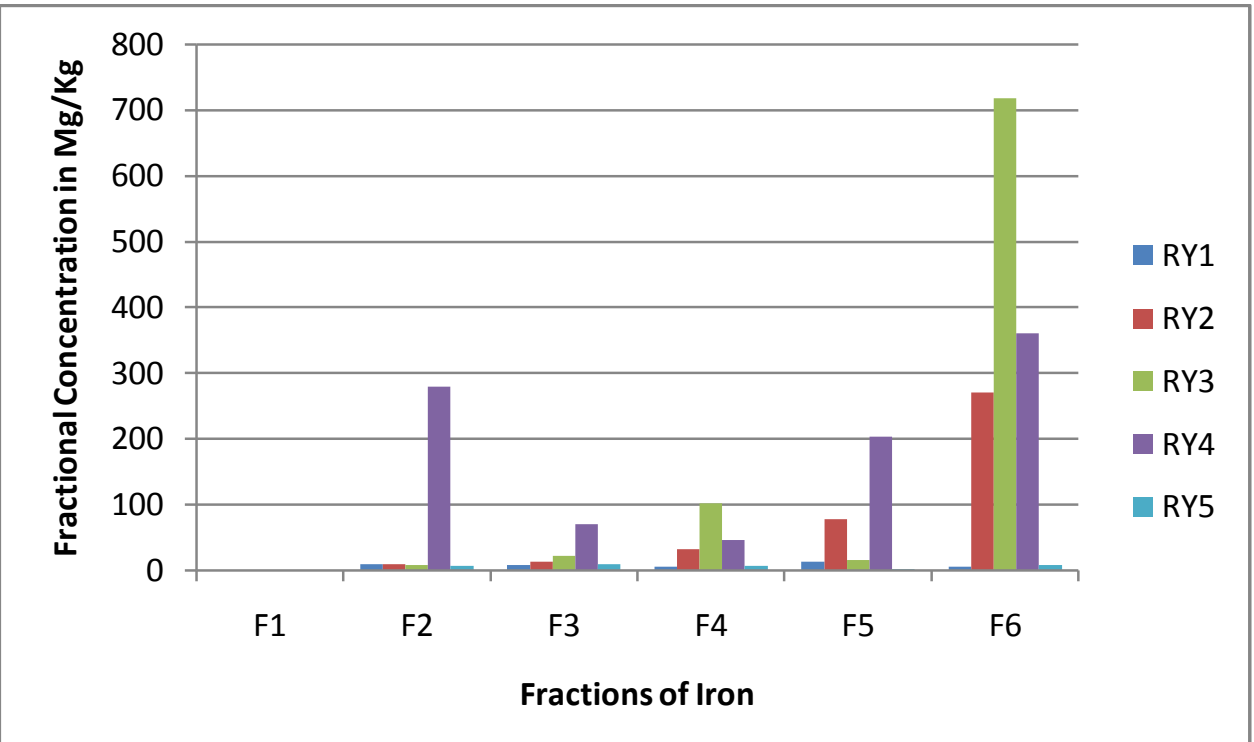

Figure 8: Fractional Concentration of Fe in the Various Soils 30cm Depth (mg/kg).

The residual fraction had the most concentration of Fe with a mean value of $272.159 \mathrm{mg} / \mathrm{kg}$ while the least was found in the water soluble fraction $(0.160 \mathrm{mg} / \mathrm{kg}$ ) (Table 9). This indicates a high level of non-bioavailable fractions of Fe and so may be from geochemical sources. The \%BAF of Fe were generally low (below 50\%) for all the samples except for RY5 which was 51.044\%. Fe was not detectable in samples RY2, RY3 and RY4 in the water soluble fractions.

Table 10: Fractional Concentration of Co in the Various Soils 30cm Depth (mg/kg).

\begin{tabular}{|c|c|c|c|c|c|c|c|c|c|c|}
\hline $\begin{array}{l}\text { Sample } \\
\text { code }\end{array}$ & F1 & F2 & F3 & $\mathrm{F} 4$ & F5 & F6 & Total & Mean & BAF & $\% \mathrm{BAF}$ \\
\hline RY1 & $\begin{array}{l}0.016 \\
\pm 0.001\end{array}$ & $\begin{array}{l}0.079 \\
\pm 0.002\end{array}$ & $\begin{array}{l}0.216 \\
\pm 0.002\end{array}$ & $\begin{array}{l}0.025 \\
\pm 0.001\end{array}$ & $\begin{array}{l}0.015 \\
\pm 0.000\end{array}$ & $\begin{array}{l}0.778 \\
\pm 0.001\end{array}$ & 1.130 & 0.188 & 0.311 & 27.547 \\
\hline RY2 & ND & $\begin{array}{l}0.070 \\
\pm 0.002\end{array}$ & $\begin{array}{l}0.143 \\
\pm 0.002\end{array}$ & ND & $\begin{array}{l}0.007 \\
\pm 0.002\end{array}$ & $\begin{array}{l}0.526 \\
\pm 0.010\end{array}$ & 0.746 & 0.124 & 0.213 & 28.552 \\
\hline RY3 & $\begin{array}{l}0.018 \\
\pm 0.006\end{array}$ & $\begin{array}{l}0.090 \\
\pm 0.000\end{array}$ & $\begin{array}{l}0.224 \\
\pm 0.001\end{array}$ & $\begin{array}{l}0.025 \\
\pm 0.001\end{array}$ & $\begin{array}{l}0.051 \\
\pm 0.002\end{array}$ & $\begin{array}{l}0.930 \\
\pm 0.028\end{array}$ & 1.338 & 0.223 & 0.332 & 24.141 \\
\hline RY4 & $\begin{array}{l}0.010 \\
\pm 0.000\end{array}$ & $\begin{array}{l}0.504 \\
\pm 0.013\end{array}$ & $\begin{array}{l}0.275 \\
\pm 0.003\end{array}$ & $\begin{array}{l}0.007 \\
\pm 0.003\end{array}$ & $\begin{array}{l}0.054 \\
\pm 0.002\end{array}$ & $\begin{array}{l}0.785 \\
\pm 0.005\end{array}$ & 1.635 & 0.273 & 0.789 & 48.257 \\
\hline RY5 & $\begin{array}{l}0.013 \\
\pm 0.003\end{array}$ & $\begin{array}{l}0.086 \\
\pm 0.002\end{array}$ & $\begin{array}{l}0.179 \\
\pm 0.001\end{array}$ & $\begin{array}{l}0.005 \\
\pm 0.001\end{array}$ & $\begin{array}{l}0.029 \\
\pm 0.002\end{array}$ & $\begin{array}{l}0.852 \\
\pm 0.002\end{array}$ & 1.164 & 0.194 & 0.278 & 23.883 \\
\hline Total & 0.057 & 0.829 & 1.037 & 0.062 & 0.156 & 3.871 & 6.012 & 1.002 & 1.923 & 152.380 \\
\hline Mean & 0.011 & 0.166 & 0.207 & 0.012 & 0.031 & 0.774 & 1.201 & 0.200 & 0.384 & 30.476 \\
\hline
\end{tabular}




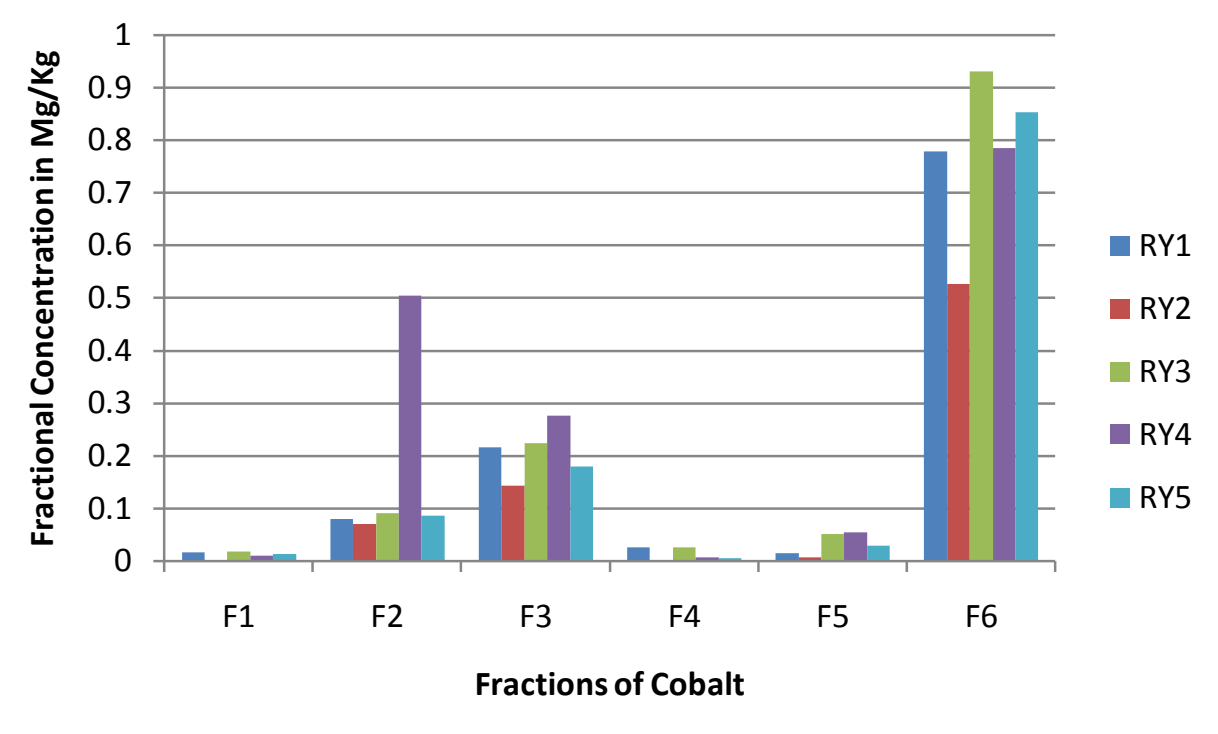

Figure 9: Fractional Concentration of Co in the Various Soil 30cm Depth (mg/kg).

Co was not detectable at the water soluble and reducible fractions in sample RY2 and the meanest concentration was recorded in the residual fraction $(0.774 \mathrm{mg} / \mathrm{kg}$ ) (table 10), while the least mean was in the water soluble fraction $(0.011 \mathrm{mg} / \mathrm{kg})$. The $\% \mathrm{BAF}$ of Co was also generally low as the value for the samples were below $50 \%$.

Table 11: Fractional Concentration of $\mathrm{Zn}$ in the Various Soil 30cm Depth $(\mathrm{mg} / \mathrm{kg})$.

\begin{tabular}{|l|l|l|l|l|l|l|l|l|l|l|}
\hline $\begin{array}{l}\text { Sample } \\
\text { code }\end{array}$ & F1 & F2 & F3 & F4 & F5 & F6 & Total & Mean & BAF & $\%$ BAF \\
\hline RY1 & 0.662 & 0.216 & 0.266 & 0.320 & 0.420 & 7.985 & 9.869 & 1.645 & 1.144 & 11.592 \\
& \pm 0.000 & \pm 0.001 & \pm 0.004 & \pm 0.005 & \pm 0.002 & \pm 0.003 & & & & \\
\hline RY2 & 0.077 & 0.246 & 0.249 & 0.344 & 0.370 & 7.098 & 8.384 & 1.397 & 0.572 & 6.823 \\
& \pm 0.004 & \pm 0.006 & \pm 0.001 & \pm 0.014 & \pm 0.009 & \pm 0.001 & & & & \\
\hline RY3 & 0.104 & 0.314 & 0.423 & 0.402 & 0.481 & 9.975 & 11.699 & 1.950 & 0.841 & 7.189 \\
& \pm 0.006 & \pm 0.000 & \pm 0.011 & \pm 0.023 & \pm 0.009 & \pm 0.011 & & & & \\
\hline RY4 & 0.012 & 6.594 & 0.328 & 0.189 & 0.341 & 12.475 & 19.939 & 3.323 & 6.934 & 34.776 \\
& \pm 0.006 & \pm 0.004 & \pm 0.001 & \pm 0.009 & \pm 0.006 & \pm 0.004 & & & & \\
\hline RY5 & 0.650 & 0.333 & 0.966 & 0.237 & 0.384 & 8.726 & 11.296 & 1.883 & 1.949 & 17.254 \\
& \pm 0.002 & \pm 0.001 & \pm 0.003 & \pm 0.006 & \pm 0.002 & \pm 0.005 & & & & \\
\hline Total & 1.505 & 7.703 & 2.232 & 1.492 & 1.996 & 46.259 & 61.187 & 10.198 & 11.440 & 77.634 \\
\hline Mean & 0.301 & 1.541 & 0.446 & 0.298 & 0.399 & 9.252 & 12.237 & 2.040 & 2.288 & 15.527 \\
\hline
\end{tabular}

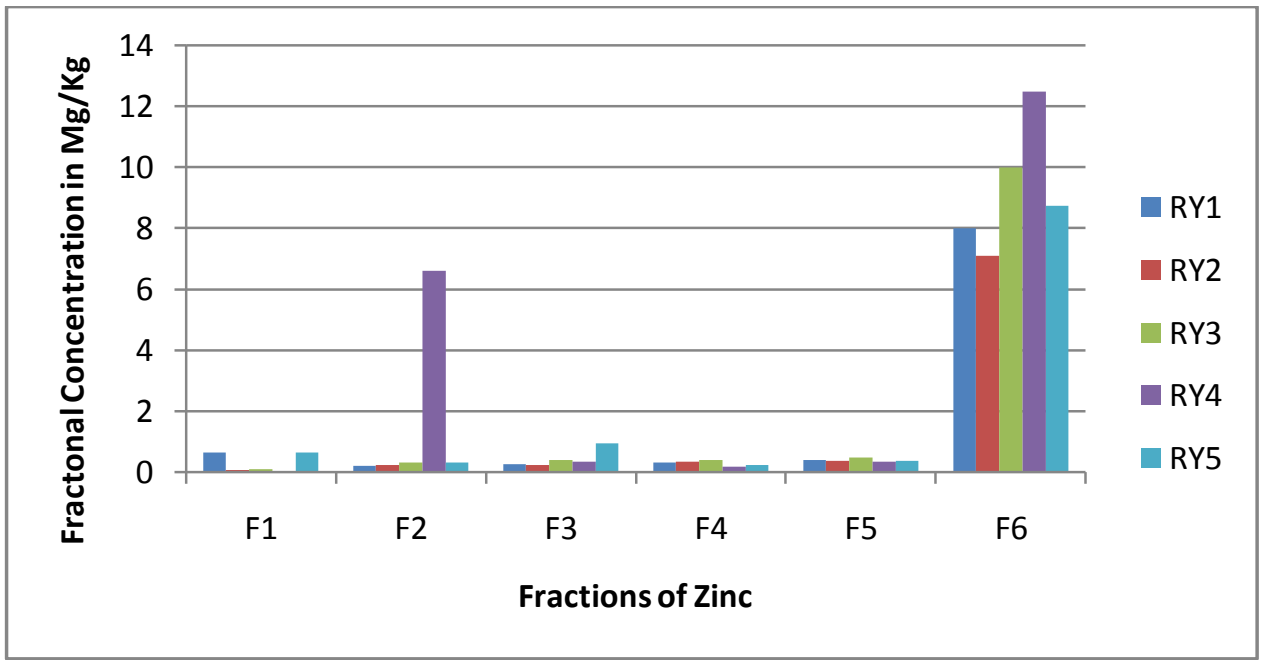

Figure 10: Fractional Concentration of $\mathrm{Zn}$ in the Various Soil 30cm Depth $(\mathrm{mg} / \mathrm{kg})$.

Sample RY4 had the highest value of \%BAF (34.776\%) while the least was recorded in sample RY2 (Table 11). The trend in the mean concentration of $\mathrm{Zn}$ in the various fractions was F6 > F2 > F3 > F5 > F4 > F1 while the 
trend in the \%BAF of $\mathrm{Zn}$ in the various soil samples is RY4 > RY5 > RY1 > RY3 > RY2. This shows that $\mathrm{Zn}$ fractionated more in the residual fraction and sample 4 (RY4) recorded the most mean concentration.

Table 12: Fractional Concentration of $\mathrm{Cr}$ in the Various Soil $30 \mathrm{~cm}$ Depth $(\mathrm{mg} / \mathrm{kg})$.

\begin{tabular}{|l|l|l|l|l|l|l|l|l|l|l|}
\hline $\begin{array}{l}\text { Sample } \\
\text { code }\end{array}$ & F1 & F2 & F3 & F4 & F5 & F6 & Total & Mean & BAF & \%AF \\
\hline RY1 & 0.032 & 0.072 & 0.192 & 0.199 & 0.244 & 0.491 & 1.230 & 0.205 & 0.296 & 24.065 \\
& \pm 0.002 & \pm 0.001 & \pm 0.003 & \pm 0.003 & \pm 0.002 & \pm 0.014 & & & & \\
\hline RY2 & ND & 0.031 & 0.100 & $\begin{array}{l}0.095 \\
\pm 0.002\end{array}$ & $\begin{array}{l}0.228 \\
\pm 0.036\end{array}$ & $\begin{array}{l}0.656 \\
\pm 0.018\end{array}$ & 1.110 & 0.185 & 0.131 & 11.802 \\
& & \pm 0.016 & & & & \\
\hline RY3 & 0.037 & 0.087 & 0.207 & 0.264 & 0.415 & 1.066 & 2.076 & 0.346 & 0.331 & 15.944 \\
& \pm 0.043 & \pm 0.012 & \pm 0.029 & \pm 0.032 & \pm 0.004 & \pm 0.006 & & & & \\
\hline RY4 & 0.076 & 0.793 & 0.308 & 0.180 & 0.513 & 1.036 & 2.906 & 0.484 & 1.177 & 40.502 \\
& \pm 0.017 & \pm 0.017 & \pm 0.019 & \pm 0.002 & \pm 0.007 & \pm 0.032 & & & & \\
\hline RY5 & 0.060 & 0.063 & 0.156 & 0.211 & 0.316 & 0.568 & 1.374 & 0.229 & 0.279 & 20.306 \\
& \pm 0.003 & \pm 0.002 & \pm 0.003 & \pm 0.005 & \pm 0.002 & \pm 0.005 & & & & \\
\hline Total & 0.205 & 1.046 & 0.963 & 0.949 & 1.716 & 3.817 & 8.696 & 1.449 & 2.214 & 112.619 \\
\hline Mean & 0.041 & 0.209 & 0.193 & 0.190 & 0.343 & 0.763 & 1.739 & 0.290 & 0.443 & 22.524 \\
\hline
\end{tabular}

Table 12 present the partitioning of $\mathrm{Cr}$ in the soil samples $30 \mathrm{~cm}$ depth. The highest mean concentration of $\mathrm{Cr}$ was recorded in the residual fraction (F6) with the value $0.763 \mathrm{mg} / \mathrm{kg}$ while the least was found in the water soluble fraction $(0.041 \mathrm{mg} / \mathrm{kg}$ ). Road 4 (RY4) had the most \%BAF and the least was recorded in road 2 (RY2). The trend in the \%BAF of $\mathrm{Cr}$ in the various soil samples was RY4 > RY1 > RY5 > RY3 > RY2 and the observed trend in the mean fractional concentration of Cr was also F6 $\square$ F5 $\square$ F2 $\square$ F3 $>$ F4 $>$ F1.

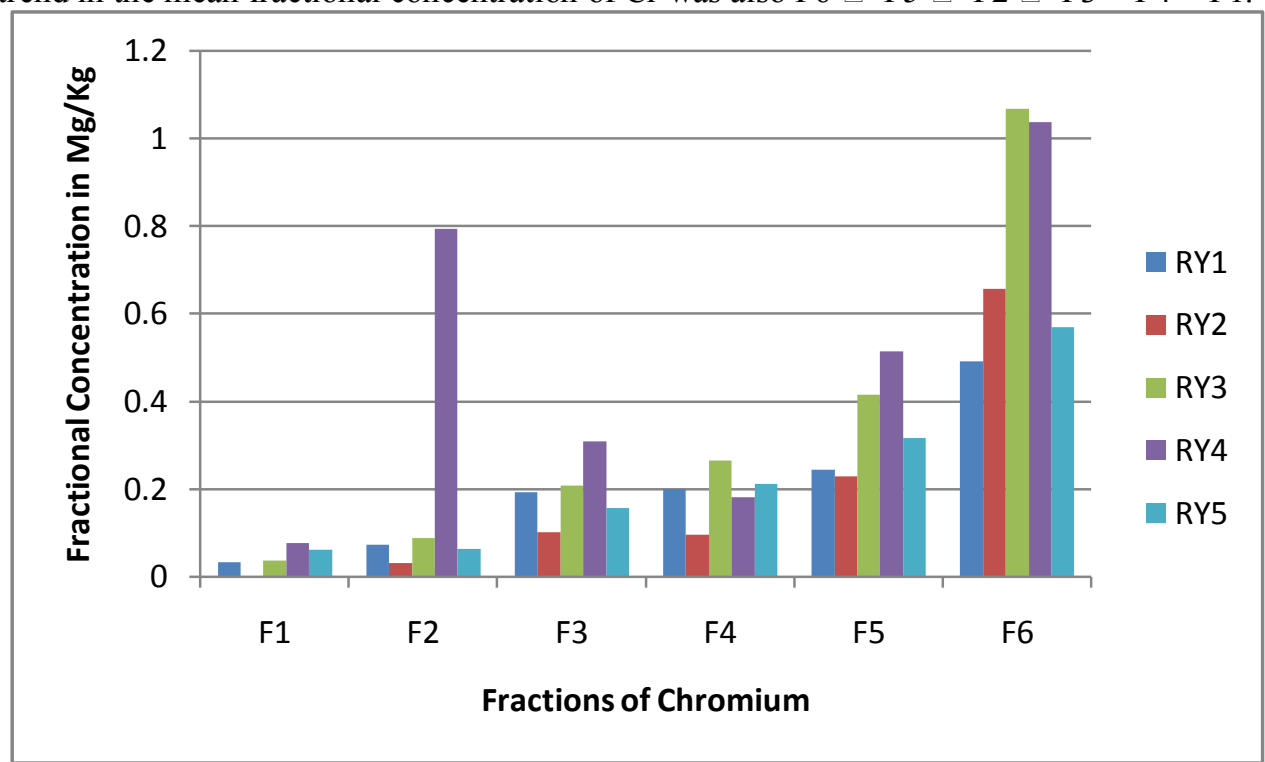

Figure 11: Fractional Concentration of $\mathrm{Cr}$ in the Various Soil 30cm Depth $(\mathrm{mg} / \mathrm{kg})$.

Table 13: Fractional Concentration of Cd in the Various Soil 30 $\mathrm{cm}$ Depth $(\mathrm{mg} / \mathrm{kg})$

\begin{tabular}{|c|c|c|c|c|c|c|c|c|c|c|}
\hline Sample code & F1 & $\mathrm{F} 2$ & F3 & F4 & F5 & F6 & Total & Mean & BAF & $\% \mathrm{BAF}$ \\
\hline RY1 & ND & $\begin{array}{l}0.016 \\
\pm 0.001\end{array}$ & $\begin{array}{l}0.046 \\
\pm 0.002\end{array}$ & ND & ND & $\begin{array}{l}0.006 \\
\pm 0.000\end{array}$ & 0.068 & 0.011 & 0.062 & 91.176 \\
\hline RY2 & ND & $\begin{array}{l}0.033 \\
\pm 0.002\end{array}$ & $\begin{array}{l}0.032 \\
\pm 0.007\end{array}$ & ND & ND & $\begin{array}{l}0.068 \\
\pm 0.003\end{array}$ & 0.133 & 0.022 & 0.065 & 48.872 \\
\hline RY3 & ND & $\begin{array}{l}0.011 \\
\pm 0.001\end{array}$ & $\begin{array}{l}0.043 \\
\pm 0.001\end{array}$ & ND & ND & $\begin{array}{l}0.103 \\
\pm 0.002\end{array}$ & 0.157 & 0.026 & 0.054 & 34.395 \\
\hline RY4 & ND & $\begin{array}{l}0.056 \\
\pm 0.004\end{array}$ & $\begin{array}{l}0.036 \\
\pm 0.007\end{array}$ & ND & ND & $\begin{array}{l}0.071 \\
\pm 0.000\end{array}$ & 0.163 & 0.027 & 0.092 & 56.442 \\
\hline RY5 & ND & $\begin{array}{l}0.051 \\
\pm 0.000\end{array}$ & $\begin{array}{l}0.041 \\
\pm 0.000\end{array}$ & ND & ND & $\begin{array}{l}0.009 \\
\pm 0.001\end{array}$ & 0.010 & 0.017 & 0.092 & 91.089 \\
\hline Total & 0.000 & 0.167 & 0.198 & 0.000 & 0.000 & 0.257 & 0.622 & 0.104 & 0.365 & 321.974 \\
\hline Mean & 0.000 & 0.033 & 0.040 & 0.000 & 0.000 & 0.051 & 0.124 & 0.021 & 0.073 & 64.395 \\
\hline
\end{tabular}




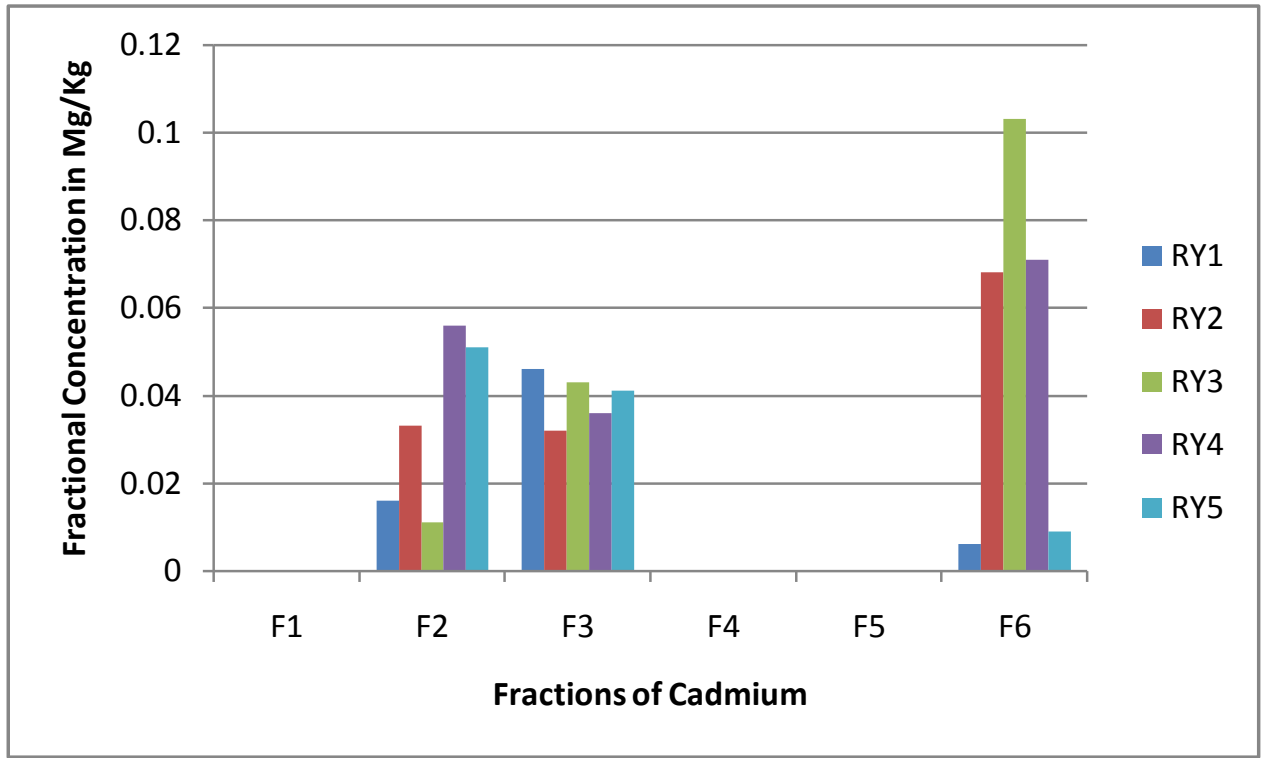

Figure 12: Fractional Concentration of Cd in the Various Soil 30cm Depth $(\mathrm{mg} / \mathrm{kg})$.

From the fractional concentration of $\mathrm{Cd}$ in the various soil sample (Table 13), we observe that $\mathrm{Cd}$ fractionated more in the residual fraction were it had the highest mean concentration of $0.051 \mathrm{mg} / \mathrm{kg}$. Cd was not detectable by the FAAS (Analyst 200) used at the water soluble fraction, reducible and the oxidisable fractions for all the samples. Road 1 (RY1) had the highest \% BAF $(91.176 \%)$. The trend for the percentage bioavailable fractions of $\mathrm{Cd}$ in the various roads was $\mathrm{Y} 1>\mathrm{RY} 5>\mathrm{RY} 4>\mathrm{RY} 2>\mathrm{RY} 3$ while the observed trend in the mean concentration of $\mathrm{Cd}$ was $\mathrm{F} 6>\mathrm{F} 3>\mathrm{F} 2>\mathrm{F} 1>\mathrm{F} 4>\mathrm{F} 5$.

Table 14: Percentage Bioavailability of Metal Concentration in the Soil $30 \mathrm{~cm}$ Depth.

\begin{tabular}{|l|l|l|l|l|l|l|l|l|l|l|}
\hline $\begin{array}{l}\text { Sample } \\
\text { code }\end{array}$ & $\mathrm{Cu}$ & $\mathrm{Ca}$ & $\mathrm{Mn}$ & $\mathrm{Pb}$ & $\mathrm{Ni}$ & $\mathrm{Fe}$ & $\mathrm{Co}$ & $\mathrm{Zn}$ & $\mathrm{Cr}$ & $\mathrm{Cd}$ \\
\hline RY1 & 50.464 & 85.545 & 24.817 & 23.473 & 15.575 & 41.772 & 27.547 & 11.592 & 24.065 & 91.176 \\
\hline RY2 & 27.791 & 86.747 & 32.166 & 15.335 & 32.784 & 5.459 & 28.552 & 6.823 & 11.802 & 48.872 \\
\hline RY3 & 15.165 & 97.321 & 24.537 & 19.058 & 22.692 & 3.453 & 24.141 & 7.189 & 15.944 & 34.395 \\
\hline RY4 & 50.615 & 93.360 & 39.103 & 60.274 & 44.431 & 36.424 & 48.257 & 34.776 & 40.502 & 56.442 \\
\hline RY5 & 42.368 & 94.071 & 35.021 & 53.310 & 21.037 & 51.044 & 23.883 & 17.254 & 20.306 & 91.089 \\
\hline GT & 186.40 & 457.04 & 155.64 & 171.45 & 136.51 & 138.15 & 152.38 & 77.634 & 112.61 & 321.97 \\
& 3 & 4 & 4 & & 9 & 2 & 0 & & 9 & 4 \\
\hline GM & 37.281 & 91.409 & 31.129 & 34.290 & 27.304 & 27.630 & 30.476 & 15.527 & 22.524 & 64.395 \\
\hline
\end{tabular}

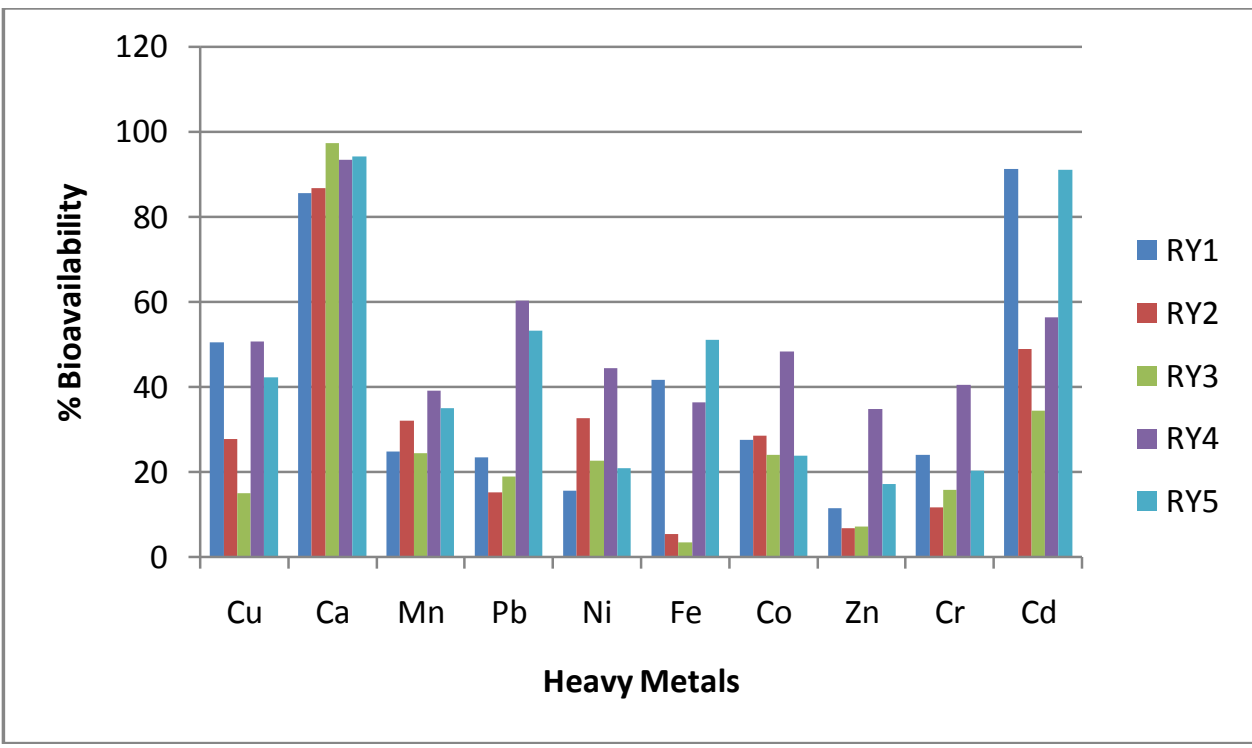

Figure 13: Percentage Bioavailability of Metal Concentration in the Soil 30cm Depth. 
The percentage bioavailability (Table 14) shows that $\mathrm{Ca}$ had the highest concentration of bioavailable fractions which is found in road $3(97.321 \%)$ and the least was recorded also in sample RY3. Ca also had the most ground mean (91.409\%) and Zinc recorded the least value of the ground mean. The trend in the percentage bioavailability of the various heavy metals was as follows: $\mathrm{RY} 1-\mathrm{Cd}>\mathrm{Ca}>\mathrm{Cu}>\mathrm{Fe}>\mathrm{Co}>\mathrm{Mn}>\mathrm{Cr}>\mathrm{Pb}>$ $\mathrm{Ni}>\mathrm{Zn}, \mathrm{RY} 2-\mathrm{Ca}>\mathrm{Cd}>\mathrm{Ni}>\mathrm{Mn}>\mathrm{Co}>\mathrm{Cu}>\mathrm{Pb}>\mathrm{Cr}>\mathrm{Zn}>\mathrm{Fe}, \mathrm{RY} 3-\mathrm{Ca}>\mathrm{Cd}>\mathrm{Mn}>\mathrm{Co}>\mathrm{Ni}>\mathrm{Pb}>\mathrm{Cr}$ $>\mathrm{Cu}>\mathrm{Zn}>\mathrm{Fe}, \mathrm{RY} 4-\mathrm{Ca}>\mathrm{Pb}>\mathrm{Cd}>\mathrm{Cu}>\mathrm{Co}>\mathrm{Ni}>\mathrm{Cr}>\mathrm{Mn}>\mathrm{Fe}>\mathrm{Zn}, \mathrm{RY} 5-\mathrm{Ca}>\mathrm{Cd}>\mathrm{Pb}>\mathrm{Fe}>\mathrm{Cu}>$ $\mathrm{Mn}>\mathrm{Co}>\mathrm{Ni}>\mathrm{Cr}>\mathrm{Zn}$. The trend for the ground mean for the various heavy metals was $\mathrm{Ca}>\mathrm{Cd}>\mathrm{Cu}>\mathrm{Pb}>$ $\mathrm{Mn}>\mathrm{Co}>\mathrm{Fe}>\mathrm{Ni}>\mathrm{Cr}>\mathrm{Zn}$.

The higher the \%BAF, the higher the availability of the metal for organism's uptake and so the more harmful it is to the organism because of the level of exposure. This is true according to J.J.K Erwin (2006). In this case $\mathrm{Ca}$ is the most available metal in the studied area.

In the correlations of the various fractions of the soil samples $30 \mathrm{~cm}$ depth, it was positive in the correlation of $\mathrm{Zn}$ and $\mathrm{Cu}$ at the water soluble fraction, positive between $\mathrm{Ni}$ and $\mathrm{Mn}, \mathrm{Ni}$ and $\mathrm{Zn}, \mathrm{Ni}$ and $\mathrm{Cr}, \mathrm{Cd}$ and $\mathrm{Cu}, \mathrm{Cr}$ and $\mathrm{Zn}$ also at the exchangeable fraction. At the carbonate fraction, it was only positive between $\mathrm{Cu}$ and $\mathrm{Ni}, \mathrm{Ca}$ and $\mathrm{Pb}$, and between $\mathrm{Cr}$ and $\mathrm{Co}$. the correlation was also positive in the case of $\mathrm{Co}$ and $\mathrm{Fe}$ at the reducible fraction and none at the oxidisable fraction but positive between the following metals ate the residual level: Mn \&, $\mathrm{Fe} \& \mathrm{Co}, \mathrm{Cr} \& \mathrm{Fe}, \mathrm{Zn} \& \mathrm{Cu}, \mathrm{Co} \& \mathrm{Cr}$ as well as in $\mathrm{Zn} \& \mathrm{Cd}$

\section{Conclusion}

The speciation of heavy metals in Owerri industrial layout showed that most of the metals considered had the highest abundance in the Residual fraction. This indicates that the metals were immobile. Ten metals were considered and $\mathrm{Cu}, \mathrm{Co}, \mathrm{Cr}, \mathrm{Zn}, \mathrm{Cd}, \mathrm{Pb}, \mathrm{Ni}, \mathrm{Mn}$ and $\mathrm{Fe}$ were found mostly abundant in the Residual fraction of the sequential extraction. This shows that soil in the environment was not likely to be polluted by these metals. Ca was found to be highly abundant in the Exchangeable fraction, indicating that it could be easily released to the environment from soil. It was also likely to be of high toxicity in the environment though it is not a heavy metal. Comparing these results obtained with the results of that reported by Abugu, et al (2012), it showed that the concentration of the heavy metals considered in the $30 \mathrm{~cm}$ depth were higher than the soil surface samples. This shows that there is a serious leaching of these heavy metals under investigation. The results of the speciation have given the present status of metal pollution and the potential pollutants in Owerri industrial area.

\section{Acknowledgements}

We wish to offer our sincerest thanks to our able supervisor, Prof. P.A.C Okoye. Professor of Environmental/Analytical chemistry, who was always available with his guidance, sympathetic attitude and encouragement through the research. The figure of Dr. P.E. Omuku, Doctor of Environmental/Analytical chemistry, was like a father ready to explain and guide us along the intricate path of research and specially for introducing us to the field of Environmental/Analytical chemistry.

\section{References}

[1] M. F. Tack and G. M. Verloo, Chemical speciation and fractionation in soil and sediment heavy metal analysis - a review. Int. J. of Environ. Anal. Chem. 59: 1995, 225-238

[2] S. Uba, A. Uzairu, and O. J. Okunola, Content of Heavy Metals in Lumbricus Terrestris and soils in Dump sites. Int. J. Environ. Res. 3(3): 2009, 353-358

[3] M. Ramirez, S. Massolo, R. Fraiche and J. A. Correa, Metal speciation and environmental impact on sandy beaches due to El. Salvador Coppermine, Chile. Marine Pollution Bulleting 50: 2005, 62-71

[4] G.O. Adewuyi, F.A. Dawodu, and N.N. Jibiri, Studies of the Concentration Levels of Heavy Metals in Vegetable (Amaranthus caudatus) Grown in Dumpsites within Lagos Metropolis, Nigeria. The Pacific Journal of Science and Technology 11(1). 2010, 616621

[5] S. Dudka, M. Piotrowska, and H. Terelak, Transfer of cadmium, lead and zinc from industrially contaminated soil to crop plants: a field study. Environ. Pollut., 94(2): 1996, 181-188.

[6] J. Scancar, R, Milacic, M, Strazar, and O. Burica Sci. Total. Environ., 250, no 1-3: 9, 2000

[7] M. Pueyo, G. Rauret, D. Lück, M. Yli-Halla, H. Muntau, Ph. Quevauviller, J.F. Lopez-Sanchez. J. Environ. Monitor. 3:243. 2001

[8] A., Tessier, P.G.C Campbell,. and M. Blsson. Sequential Extraction Procedure for the Speciation of Particulate Trace Metals. Analytical Chemistry, 51(7), 1979, 844-845.

[9] J.J.K. Erwin,, Chemical Speciation and Bioavailability of Heavy Metals in Soil and Surface Water. Wageningen University, Wageningen, Netherlands. p.10. 2006.

[10] Abugu, H. O., Okoye, P. A. C. and Omuku, P. E., Evaluation of the speciation patterns of some heavy metals along the major roads of Owerri industrial layout. Int. Org. of Sci. Research, 2012, unpublished paper 